Sign Systems Studies 46(1), 2018, 168-177

\title{
On the analysis of power and politics from the perspective of Juri Lotman's semiotics of culture
}

\section{Andreas Ventsel, Taras Boyko ${ }^{1}$}

Review of Juri Lotman's Cultural Semiotics and the Political [Series Reframing the Boundaries: Thinking the Political] by Andrey Makarychev and Alexandra Yatsyk. London: Rowman \& Littlefield, 2017, 228 pp.

In 2017, Andrey Makarychev and Alexandra Yatsyk published a monograph entitled Juri Lotman's Cultural Semiotics and the Political. Andrey Makarychev is a Visiting Professor at the Johan Skytte Institute of Political Science, University of Tartu. His areas of expertise include contemporary political theories, issues of biopolitics and regionalism, and Russian foreign and security policies. Alexandra Yatsyk is Alexander Herzen Junior Visiting Fellow at the Institute for Human Science in Vienna, Austria and Visiting Researcher at the Centre for Russian and Eurasian Studies of Uppsala University, Sweden. She is an author and editor of works on post-Soviet nationbuilding, sports and cultural mega-events, biopolitics and art.

The position and legacy of the Tartu-Moscow School in the context of 20th-century humanities is not a new subject in academic literature: a quick overview includes, e.g., Shukman 1977, Andrews 2003, and Semenenko 2012, all of which concentrate on the evaluation of the legacy of the Tartu-Moscow School from the perspective of literary theory. From a sociological perspective, Hartley 2012 is focused on complementing theories of semiotics of culture with evolutionary economics and the dynamics of innovation in the context of new media. Peet Lepik (2007) has studied universals in the context of Lotman's semiotics and Max Waldstein (2008) presents a holistic historical picture of the activities of the Tartu-Moscow School in Soviet-era academe in the framework of intellectual history and historical sociology.

To move on to connections with political theory, doctoral theses defended in Estonia during the last decade by Daniele Monticelli (2008), Andreas Ventsel (2009),

1 Authors' address: Department of Semiotics, University of Tartu, Jakobi 2, 51014 Tartu, Estonia; e-mail: andreas.ventsel@ut.ee, taras.boyko@ut.ee. 
Peeter Selg (2011), and Mari-Liis Madisson (2016) all attempt to synthesize concepts of cultural semiotics with different approaches of political theory, analysing phenomena such as, for example, the rhetoric of the Stalin era and the discursive strategies of online communication of the extreme right.

\section{Cultural semiotics and politics}

According to many social scientists, semioticians and semiotics as a discipline have avoided problems of politics and political theory (see Mandoki 2004; Ventsel 2011), apart from a few exceptions, such as the essays by Roland Barthes (1973) and Umberto Eco (1995). Pertti Ahonen (1990: 8) has noted that unfortunately, the semiotic expansion that started in the 1970s is in many cases characterized by the fact that expertise in semiotics is not complemented by expertise in the field to which semiotics is applied. This is also true for the interdisciplinary approaches connecting political studies and semiotics. Boris Uspenskij, member of the Tartu-Moscow School and frequent co-author of Juri Lotman, criticizes the use - or, more precisely, the nonuse - of semiotics in analyses of power from a slightly different perspective:

I think that the French (especially Kristeva and others) played here a destructive role since they replaced an attempt to pursue honest research with ideology. This, in turn, brought about a defensive reaction, because, if you are dealing in ideology, you are already dependent on current fashions. (Uspenski 2002).

According to Uspenskij (2012: 23),

The Iron Curtain favoured the concentration of researchers; ideological pressure awoke the desire to be intellectually free, and determined the renunciation of any ideological judgments. [...] The Moscow-Tartu School of Semiotics had emerged under the conditions of internal resistance; but it did not strive towards resisting Soviet reality, as much as towards complete independence.

This statement simply feels like an attempt at non-ideological self-description. As a researcher in the Soviet Union, one could not possibly deal with contemporary "hot topics" - be they politics or power relations -, since that would have necessarily brought along the recognition of the research object as a semiotic reality by the authorities. They were rather "forced" to choose - more or less wittingly - either Pushkin or icons as their objects of interest. Otherwise, their research would have been taken as potential criticism of the dominant political order. 
The above does not mean that problems of power were completely absent from the School's field of interest: vivid examples of these are provided by the cultural semiotic analyses of the power games of Peter the Great or Ivan the Terrible, as well as the semiotic terminology created by the School ('centre' and 'periphery'; 'hierarchy'; the opposition between 'culture' and 'anti-culture', etc.) It is the application of these concepts to contemporary political phenomena that Makarychev and Yatsyk's book deals with. The goal is, on the one hand, to demonstrate the feasibility of cultural semiotic analyses of political processes, and, on the other hand, to complement approaches in political theory with ideas of cultural semiotics. In the latter case, a dialogue with authors such as Foucault, Badiou, Agamben, Lacan, Rancière, etc. is created. The authors try to demonstrate "how the discipline of cultural semiotics can help overcome the crisis of dominating vocabularies of political science - with their focus on institutions, political elites, interests, decision-making procedures, and policy tools and resources established after the end of the Cold War and the fall of the Soviet Union" (Makarychev, Yatsyk 2017: ix). And Makarychev and Yatsyk indeed succeed in what they set out to do.

The paramount message the book accentuates is that due to the "heterogeneity of the post-Soviet" and a certain "weakness of political science in producing explanatory frameworks for the post-Soviet condition" (Makarychev, Yatsyk 2017: xi) the door is open to experimentations with alternative conceptual languages of analysis. In other words, reliance on the accepted and widely used political language(s)/dominating vocabulary can and should be complemented by the viewpoint(s) of cultural semiotics, and this is what Juri Lotman's Cultural Semiotics and the Political tries to offer its readers.

In the introductory section the authors briefly stop on a very important and, as it seems, extremely relevant note that the post-Soviet space needs semiotic readings (Makarychev, Yatsyk 2017: xxiv). In this regard, an inevitable question will emerge whose ideas can offer us a better "semiotic reading" of this region and its heterogenic realia than those coming from Juri Lotman, a scholar and public intellectual who promoted such semiotic readings throughout his entire career? The use of Lotmanian language appears to be a very adequate choice in this case, not only due to the fact that Lotman himself "belonged to the worlds of the Soviet and the post-Soviet" (Makarychev, Yatsyk 20017: xxviii), but also the fact that he knew and, in some sense, even "felt" this space, including the logic of its historical developments and the trajectories on which it was moving (on cultural, political and other levels). Makarychev and Yatsyk's idea to bring the conceptual language of the Tartu-Moscow School and Juri Lotman's ideas in particular into the picture also seems to help overcome the rather long tradition of trying to describe the post-Soviet realia using only imported "Western" (political) language, which, more or less since the collapse 
of the Iron Curtain, has been assumed to be somehow superior and more appropriate, simply due to its non-Soviet/non-Socialist-bloc/non-peripheral origin. One of the key merits of the reviewed book is related to the fact that the authors do not reject one conceptual language in favour of another, but instead try to show all those 'similarities', 'parallels', 'affinities', 'translatabilities', etc., between the Lotmanian language and the widely accepted "classics" of Western political science and philosophy - basically, what the former can offer and how it can complement the existing approaches.

The book is divided into four larger sections that are accompanied by a thorough introduction which gives a general overview of the subject and argues for the usefulness of a cultural semiotic approach to the analysis of post-Soviet socio-cultural processes. In addition, some of the Soviet-era specificities of scholarly practices limiting the Tartu-Moscow School's involvement in analysing contemporary political processes are highlighted. The book ends with a conclusive glance into the future ("Conclusion: How to read Lotman in the twenty-first century?") in which the authors discuss the consequences stemming from the inherent ambiguity of Lotman's cultural semiotic concepts (Makarychev, Yatsyk 2017: 184).

The core of the book is comprised of the following sections: (1) "Boundaries and the political: A cultural-semiotic contribution to the debate"; (2) "Beyond the semiosphere: Signifying corporeality and displacements"; (3) "Excavating the Soviet: From explosion to erasure"; and (4) "Playing games with Europe: Between accommodation and subversion". As can be gathered from the titles, each section concentrates on the application of a specific term elaborated by Lotman in the framework of political studies. Fortunately, Ahonen's fear is, in this case, ungrounded: despite the authors' non-semiotic background, they present a strong attempt to develop a theoretical framework demonstrating a thorough knowledge of the main ideas of cultural semiotics. Especially enjoyable are the re-readings of cases that, at first glance, have nothing to do with analyses of power, so as to accommodate these into the framework of contemporary political theory.

At the end of each section, the applicability of the conceptual framework is explicated through particular cases, a strategy that adds great value to a book with theoretical inclinations. These cases concentrate mainly on the analysis of Russian, Estonian, Ukrainian, and Georgian political processes and identity creation. The material is approached both on the local and the global (international relations) level. A good illustration here is the analysis describing the tensions in Georgian and Ukrainian identity creation processes as being drawn politically towards the West, but culturally and religiously towards the East (Makarychev, Yatsyk 2017: 44-52). Most importantly, the theoretical framework can successfully be applied to the material and adds explanatory value to understanding these phenomena. 
Several examples of fruitful results of interdisciplinary approaches can be found in the book, for instance, the reconceptualization of the post-structuralist concept 'suture' as Lotman's understanding of the 'border', and its application to the political processes of identity creation. According to the authors,

The most important characteristic of suture is the subject's ability to borrow meanings from outside (from external semiospheres) in order to stabilize her/ his own dispersed/dislocated identity. Foreign texts become indispensable for cementing a set of meanings constitutive of subject's identity. (Makarychev, Yatsyk 2017: 28)

A problematic aspect, however, lies in the undertheorization of the dynamism of meaning-making: how to reconcile the tension between the static and the dynamic on the theoretical level of identity creation? How to speak not of an identity that represents a stable state, but of identification as a continuous process. According to the authors, Lotman's concept of the border enables one to relax the totalizing suture of the significational space, since " $[\mathrm{t}]$ he border is a bilingual mechanism, translating external communications into the internal language of the semiosphere and vice versa" (Lotman 2005: 210). We are dealing here with a continuous dialogue in the process of which the sender and the receiver are constitutively transformed. At the same time, the concept of the border makes it possible to create a distance from the Lacanian psychoanalytic connotations.

In addition, Lotman's concept of the border (the opposition semiotic-extrasemiotic) enables us to shed light on the demarcation lines of the political field itself: what is included in politics, in culture, in art, in biology, and, furthermore, is the drawing of these borders even meaningful? If we admit that it is meaningless, shall we not lose sight of the research object altogether? The authors use the cultural semiotic borders to reconceptualize Agamben's notions of "bare life" as "a physical existence under the conditions of survival beyond any meaningful forms of representation and mediation" (Makarychev, Yatsyk 2017: 70) and Jacques Rancière's concept of the political as "the distribution of the sensible" that determines interpretations and perceptions of reality, and thus enables the formation of a semiotic sphere of shared meanings (Makarychev, Yatsyk 2017: 80). Analysing cases from song festivals to works of art (films, visual art) dealing with social trauma, the authors demonstrate how the political aspect of dialogical translations lies in their ability to produce "new meanings exactly through transgressions and intrusions from the allegedly extrasemiotic reality to the semiospheres of mass media, popular culture, and political debates" (Makarychev, Yatsyk 2017: 76), as 
[d]istinctions between texts and non-texts are relational, situational, and contextual, [...] each system of signification at certain points faces the challenge of incorporating ideas that might be disturbing for the coherence of its dominant ideological core. There are always possibilities that extra-semiotic spaces can be resignified and included in the dominant system of meanings. (Makarychev, Yatsyk 2017: 79)

\section{Some critical remarks}

In addition to the overall positive impression of the book, though, also some more problematic aspects could be pointed out. At times it seems that the authors have not used the whole potential of Lotman's cultural semiotics in their political analyses. E.g., Makarychev and Yatsyk seem to underestimate Juri Lotman's contributions related to the highly "political" topics such as the so-called Decembrists' Revolt, the system of ranks in the Russian Empire, the ideas of the "radical" 18th-century author Alexander Radishchev, etc. It is certainly true that Lotman's scholarly legacy is extremely rich and it is clear that some choices had to be made as to which ideas to use and which to discard. However, in order to diversify the tools of analysis, the concept of 'translation', but most of all, that of 'untranslatability' could have been better elaborated.

In several places, the authors point out that Lotman's models of meaning-making get somewhat stuck in the description of static and totalizing mechanisms. To a degree, this is certainly true: if in the 1970s deconstructive literary theory declared its approach to be negative in relation to the text and concentrated on the ruptures of text(ure), the destabilizing devices behind every speech act, and the analysis of discontinuities - this approach then started to prevail in the humanities as a whole (Gasparov 1993) - the aim of cultural semiotics was exactly the opposite. The text was understood as a paradoxical phenomenon. On the one hand, it is a whole demarcated by concrete borders - otherwise it would not be perceptible as a text in the first place. On the other hand, the text is a whole that emerges from openness, from the interplay and multiplicity of heterogeneous, non-calculable elements. The possibilities of interpretation cannot be forced into any a priori structures, since the text contains unlimited potential due to the interplay of its components and sources. That is, the text is first and foremost a theoretical construct in which (de)limiting serves a heuristic purpose and does not so much characterize the object language.

This kind of ontology is clearly present in Lotman's article "The phenomenon of culture" (Lotman 2004) where he speaks of meaning-making or translation in conditions of untranslatability. On its most fundamental level the activity of meaningmaking is here reduced to translation between continual and discrete codes in which meaning is formed mostly through the establishment of socio-cultural equivalence; traces of contingency, however, are preserved in the ontology of the meaning-making 
activity. Lotman does not stress the totalizing consequences of delimiting (and the act of delimiting is always accompanied by exclusion, that which lies outside of borders) that would close off the significational process. This kind of closure is perceptible only from the internal, self-descriptional perspective of a significational unit (for example, a social group, national culture, etc.); for a researcher of culture, however, the text is first and foremost the bearer of a function (Ivanov et al. 1998[1974]: 6).

From a cultural semiotic perspective these sutures of the significational process could, in fact, be conceptualized as translation, and not solely in a totalizing sense. Lotman's earlier works that concentrated on analyses of specific texts (for example, The Structure of the Artistic Text) would offer several tools for empirical analysis, such as the multiplicity of codes and recoding on both the internal and the external levels. ${ }^{2}$ This multiplicity could then be conceptualized in the context of more general cultural mechanisms, such as the oppositions culture-non-culture or culture-anticulture. ${ }^{3}$ This approach would have added explanatory value to the comparative analysis of identity creation in the cases of Russia, Georgia, Ukraine and Estonia. On a theoretical level, the employment of one of the fundamental oppositions of political analysis, that of antagonism-agonism, could have formed a bridge between ontological concepts and concrete significational mechanisms.

What also seems somewhat puzzling is the authors' varying choices in referring to the legacy (conceptual language) they set out to introduce and promote. The title of the book, as well as early introductory remarks, suggest that the book will be focused on "exploring Lotman's legacy" (Makarychev, Yatsyk 2017: viii); however, readers soon learn that "This book is rather about [...] elements of the rich legacy of the TartuMoscow school" (Makarychev, Yatsyk 2017: xxviii). Later on we find mentions of and references to "Lotman's school", "Lotman-centered circle", "Tartu school", "Soviet semiotics", etc., throughout the text, so that from a readers' perspective those appear to be used almost interchangeably. As a result, the potential reader might end up with a very simple question: is the book about "Lotman's legacy" or "Tartu-Moscow legacy"? Or perhaps it is more or less the same for the authors? Another question rises as well: what is actually meant by "Lotman's school" in this case, or who belonged to the "Lotman-centred circle"? Those questions might sound a bit strange, yet for those familiar with the history of the Tartu-Moscow School it is more than clear that although Lotman was the informal leader of the School, we definitely cannot say that Lotman equals the Tartu-Moscow School or vice versa ${ }^{4}$.

2 In political analysis, this multiplicity of coding has been applied by Selg and Ventsel (2010)

3 The opposition of culture-anticulture has been used in political analysis by Lepik (2002), Ventsel (2010), Madisson, Ventsel (2016).

4 Even the "manifesto" of the cultural semiotics Theses on the semiotic study of cultures (as applied to Slavic texts) (Ivanov et al. 1998[1974]) was not written by Juri Lotman alone. 
Makarychev and Yatsyk themselves admit that "the whole intellectual legacy of the Tartu-Moscow School is a matter of incessant polemics [...]" (Makarychev, Yatsyk 2017: xviii), so perhaps in a situation like this the primary agenda and scope of the book could have been elaborated more precisely, clearly delimiting the field which was destined to become the source of the "alternative conceptual language". Juri Lotman's legacy definitely prevails in the book, yet on a number of occasions the authors have decided to introduce certain ideas coming from Boris Uspenskij, Mihhail Lotman, Daniele Monticelli and Vladimir Toporov, and those are justified and relevant. However, in other instances when the potential reader might expect to find thematic contributions from Juri Lotman's colleagues from the Tartu-Moscow School, such contributions have not been introduced (e.g. in the section "Between politics and its reversals", when talking about 'political', 'anti-political' and 'post-political', it was surprising not see Boris Uspenskij's ideas on the matter). The selection principles for the non-Lotmanian ideas thus remain vague.

As mentioned above, the main value of the book lies in the enrichment of the theoretical concepts of political analysis with the ideas of semiotics of culture. Thus it seems somewhat peculiar that several authors, such as Foucault and Lacan, have been approached only through secondary interpretations, and not referred to directly. This does not necessarily diminish the value of the synthesis, but it is sometimes difficult to tell whether we are dealing with the bringing together of Lotman and Lacan or, indeed, Lotman and Žižek (who is used to interpret Lacan). A somewhat similar issue arises concerning Lotman's ideas. On a number of occasions throughout the book Makarychev and Yatsyk, while presenting Lotman's understanding of some particular phenomena or his approach to an issue discussed, actually do not refer to Lotman's work, but rely on secondary interpretations, most often Daniele Monticelli's, Maxim Waldstein's and Andreas Schönle's readings of Lotman. These contemporary scholars have certainly made interesting observations and interpretations, yet addressing the primary sources directly would definitely enhance the validity of the authors' arguments and perhaps even create a debate about certain interpretations made by previous scholars.

Also, some conceptual connections between Lotman's ideas and other disciplines seem somewhat forced, such as the reference made to the Copenhagen School of security studies (Makarychev, Yatsyk 2017: 67). As its connections to Lotman remain undertheorized, its inclusion does not appear to be necessary. Scholars studying Lotmanian academic heritage might also point out that Makarychev's and Yatsyk's overreliance on late Lotman (i.e., his works mainly from the 1980s and the early 1990s) partly disregards the history (i.e. emergence, modifications, transformations) of the concepts he introduced into the scholarly use (e.g. starting with the most basic concept of 'text', the pre-semiospheric understanding of 'border', the early 'game' concept, 
etc.). Nevertheless, Lotman's Cultural Semiotics and the Political is indeed a very good and thought-provoking first chapter of a yet-to-be-finished novel exploring Juri Lotman's (as well as the Tartu-Moscow School's) legacy in thinking about the political.

Almost 25 years ago Pertti Ahonen (1993) wrote about a Copernican revolution in political science, above all impelled by introducing a semiotic perspective into political science, which should eventually enrich the methodological underpinnings of the latter. According to some authors (Drechsler 2009: 74), political semiotics as a field has been regressing more than progressing since then. One can hope that recent developments such as the above-mentioned doctoral theses as well as Makarychev and Yatsyk's book will revise such estimations. In any case, the book marks a major step towards improving the situation.

\section{References}

Ahonen, Pertti 1993. A Copernican revolution in political research: Reflections on the rainbow of essays in this book. In: Ahonen, Pertti (ed.), Tracing the Semiotic Boundaries of Politics. Berlin: Mouton de Gruyter, 1-27.

Andrews, Edna 2003. Conversations with Lotman: Cultural Semiotics in Language, Literature, and Cognition. Toronto: University of Toronto Press.

Barthes, Roland 1973[1957]. Mythologies. (Lavers, Annette, trans.) London: Granada.

Drechsler, Wolfgang 2009. Political semiotics. Semiotica 173(1/4): 73-97.

Eco, Umberto 1995. Ur-fascism. The New York Review of Books 11: 12-15.

Gasparov, Boris 1993. Literaturnye lejtmotivy: Ocherki po russkoj literatury XX veka. Moscow: Nauka, 274-303. [Литературные лейтмотивы: Очерки по русской литературы ХХ века. Москва: Наука, 274-303.]

Hartley, John 2011. Digital Futures for Cultural and Media Studies. West Sussex: John Wiley \& Blackwell.

Ivanov, Vladimir; Toporov, Vladimir; Pjatigorskij, Aleksander; Lotman, Juri; Uspenskij, Boris 1998[1974]. Theses on the Semiotic Study of Cultures (As Applied to the Slavic Texts). (Tartu Semiotics Library 1.) Tartu: Tartu University Press.

Lepik, Peet 2002. The anticulture phenomenon in Soviet culture. Semiotica 138(1/4): 179-203.

- 2007. Universals in the Context of Juri Lotman's Semiotics. (Tartu Semiotics Library 6.) Tartu: Tartu University Press.

Lotman, Juri 2004[1978]. Fenomen kul'tury. In: Lotman, Yu. M. Semiosfera. St. Petersburg: Iskusstvo-SPB, 568-580. [Лотман, Ю. М. 2004. Феномен культуры. In: Лотман, Ю. М., Семиосфера. Санкт-Петербург: “Искусство-СПБ”, 568-580.]

- 2005. On the semiosphere. Sign Systems Studies 33(1): 205-229.

Madisson, Mari-Liis 2016. The Semiotic Construction of Identities in Hypermedia Environments: The Analysis of Online Communication of the Estonian Extreme Right. Tartu: University of Tartu Press.

Madisson, Mari-Liis; Ventsel, Andreas 2016. Autocommunicative meaning-making in online communication of Estonian extreme right. Sign Systems Studies 44(3): 326-354. 
Makarychev, Andrey; Yatsyk, Alexandra 2017. Juri Lotman's Cultural Semiotics and the Political. London: Rowman \& Littlefield.

Mandoki, Katya 2004. Power and semiosis. Semiotica 151: 97-114.

Monticelli, Daniele 2008. Wholeness and its Remainders: Theoretical Procedures of Totalization and Detotalization in Semiotics, Philosophy and Politics. Tartu: University of Tartu Press.

Selg, Peeter 2011. An Outline for Theory of a Political Semiotics. Tallinn: Tallinn University Press.

Selg, Peeter; Ventsel, Andreas 2010. An outline for a semiotic theory of hegemony. Semiotica 182: 443-474.

Semenenko, Aleksei 2012. The Texture of Culture: An Introduction to Yuri Lotman's Semiotic Theory (Semiotics and Popular Culture). New York: Palgrave MacMillan.

Shukman, Ann 1977. Literature and Semiotics: A Study of the Writings of Yu. M. Lotman. Amsterdam: North-Holland Pub. Co.

Uspenskij, Boris 2002. Intervjuu Boriss Uspenskiga. Postimees 21.09.

- 2012. Vene kultuuri jóujooni: Valik artikleid. Tartu: Ilmamaa.

Ventsel, Andreas 2009. Towards Semiotic Theory of Hegemony. Tartu: Tartu University Press.

- 2010. The construction of the Stalinist post-war (1944-1953) "Soviet People": A concept in the political rhetoric of Soviet Estonia. Applied Semiotics/Sémiotique appliquée 10(25): 73-83.

- 2011. Hegemonic signification from cultural semiotics point of view. Sign Systems Studies 39(2/4): 58-88.

Waldstein, Maxim 2008. The Soviet Empire of Sign: A History of Tartu School of Semiotics. Saarbrücken: VDM Verlag Dr. Müller 